\title{
Re-Evaluating The Underlying Premises Of Free Market Privatization In Current Dispensation
}

Darlington C. Richards, Morgan State University, USA Gladson I. Nwanna, Morgan State University, USA

\begin{abstract}
The contextual framework or policy orthodoxy persuading the implementation of privatization was the prevalent thinking that economic systems functioned best in a "free market", with little or no government intervention. In the same vein was the belief that a more productive allocation and rationalization of factors of production will dictate a wholesale transfer from public to private sector of the ownership and control of productive assets, their allocation and pricing, including the residual profits flowing from them. The most effective vehicle for such implementation of free market privatization was adjudged to be unfettered deregulation. To the extent that it enabled the untangling of bureaucratic impediments to the inflow and retention of capital to the countries by way of foreign direct investment (FDI) and portfolio investment (PI), including the repatriation of resultant profits, it was a welcome outcome. Unfettered deregulation, as clearly manifested in recent years, particularly in well-known developed economies, appears to have produced an outcome substantially inconsistent with the traditional suppositions, begging the obvious question in the minds of academicians and policymakers alike. Where to, from here? The answer to the apparent conflict and/or contradiction is more urgent in the developing and emerging economies where privatization, and in a broader sense, the ideas and practices based on free market principles and on free market prescriptions have been promoted and sold as sacrosanct, if not necessary for their economic growth and survival. Given the current state of the global financial market which, at best, can be said to be in a state of flux, and the myriads of supposedly economic development initiatives invoking the likes of privatization and deregulation, we are tempted to ask the following questions: Are there any fixes? Could there be better, more accommodating alternative assumption( $(s)$, doctrine $(s)$ or paradigm $(s)$ ?
\end{abstract}

Keywords: Free-Market; Privatization; Deregulation; Global Economy; Bretton Woods

\section{INTRODUCTION}

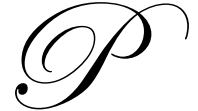

economy.

rivatization and deregulation were cloaked with such cure-all infallibilities as a model for free global market development that it was believed to be disruptive and an interference with any attempt at regulatory oversight, especially those that sought to moderate commanding sectors of the global

The substance of this tenet and its intellectual justification shall be evaluated later in the body of this work, especially in relation to developing countries. Suffice it to say at this point that the exercise in massive privatization and deregulation as propagated, encouraged, and practiced by the developed economies, with the resultant catastrophic global market meltdown, portend a monumental indictment of the free market policy orthodoxy. It is even more so when viewed against the backdrop of the huge failure in the world's most sophisticated economies. In contention, therefore, is whether this failure is procedural or structural. In other words, is privatization and deregulation intrinsically and fundamentally tenable, but lacking in appropriate implementation modalities? Or is 
there an environmental variable that affects outcomes differently, depending on regulatory structure and other institutional support infrastructure?

\section{PRESUMPTIVE TENETS}

Privatization and deregulation were cloaked with such cure-all infallibilities as a model for free global market development that it was believed to be disruptive and an interference any attempt at regulatory oversight, especially those that sought to moderate commanding sectors1 of the global economy. Complementing that believe was the contention that financial deregulation enabled the removal of barriers to capital flows, allowing unrestricted trading of abstruse financial products, with their imploratory consequences on both national economies and investments flows. The faith in financial market deregulation was so absolute in its orthodoxy and the failure to regulate so spectacular in outcome that the major economies of the world are still grappling with the cascading disruptions of that inertia. The former chairman of the Federal Reserve, Alan Greenspan, who totally and completely believed in unfettered free market, would concede that he had "found a flaw" in his bedrock belief of " 40 years or more" that markets would regulate themselves. "I made a mistake," he said (The New York Saturday, October 25, 2008). The rather universal institutional support, postulations and arguments in support of the inevitability and relevance of global stock and capital flows resulted in monumental financial market failure, indeed requiring huge and unparalleled government infusion of capital. It would appear that "governments, not the free markets, became the answer and not the problem", contrary to the popular assumptions of free market orthodoxy. It became apparent that government intervention was crucial. Nothing can be as revealing as the comments attributed to US Treasury secretary, Henry Paulson, that "...leaving businesses and consumers without access to financing (read government infusion of capital) is totally unacceptable" (The Economist, 2008).

From the US to Japan and much of Europe, governments now own stakes in the nation's biggest banks and other corporations. Some analysts are of the opinion that the stabilization of the financial markets may necessarily compel national governments' intervention, bordering on whole-sale nationalization of major banks and financial institutions (New York Times, February 21, 2009). In the US, for example, the government owns or guarantees more than half the mortgage instruments or mortgage-backed financial instruments. Finance - the lifeblood of capitalism - has, to a substantial degree, been taken over by the state (The New York Saturday, October 25, 2008). What is obvious is that deregulation, embodied in privatization, as propagated by free market orthodoxy, is untenable and dare we say, unresurrectable. It would appear that a more realistic and pragmatic re-formulation of the fundamentals of free market tenets, including capital and security instrument flows across the globe, has become imperative. To be successfully implementable will require the full and equal participation of the developed, emerging and underdeveloped economies housed in a multilateral institution along the Bretton Woods institution's model.

\section{DETERMINING CRITICAL ISSUES}

It is ironic that the unraveling of the global capital markets was precipitated by the actions of the same multinational institutions from which the Bretton Woods institutions have substantially borrowed the model of privatization and deregulation for implementation in emerging and underdeveloped economies. Whether or not the implementations of these "borrowed" models have achieved their stated objective or are responsible for the global market failure is still debatable. What is obvious is that these models have viral market place correlationships.

It is perhaps appropriate to evaluate the consonance and determinative relationship between privatization and deregulation embodied in the structural adjustment programs of these countries, which substantially advocated the total and complete non-interference by government and allowing market forces to determine factors allocation based on market and demand conditions.

\section{IDEOLOGICAL CONFLICT IN REDEMPTIVE APPLICATION}

Governments all over the world, who have come to the rescue of these ailing corporations in their home countries, have undertaken a plethora of initiatives aimed at not only stabilizing their domestic financial markets, but the global economic and market environment. It is very instructive that traditionally and prior to the melt down, the 
common practice among major industrial countries has been one of cooperative fiscal and monetary policy coordination between them, especially the Organization for Economic Cooperation and Development (OECD), the G7 and, most currently, even if tenuously, the G20. The suddenness and the extremely incremental affectation of the financial market disruption through countries have dictated an unusual "country-first" reactionary response; one dangerously premised on patriotic nationalism, or what Hill (2009) calls "pragmatic nationalism", and a rather myopic, inward-looking protectionism, which is threatening to undermine and unravel the multilateral institutional support infrastructure, sustaining global markets and investment flows. For instance, the American Recovery and Reinvestment Act of 2009 has a "Buy- America" provision that has much of the country's trading partners concerned. In the United Kingdom, the stimulus package contains proposals that are tailored along the lines of 'Buy Britain". In the proposal for economic relief, Nicolas Sarkozy pointedly warned the auto industries in France, to unsettling regional outrage, that he did expect companies receiving aid to move a factory "to the Czech Republic or elsewhere" (New York Times, 2009 A9).

In an attempt to contain this global financial contagion, the United Kingdom appears to have led the way by initiating the first bold, wholesome approach at resolution. Gordon Brown had persuaded a very irresolute and reluctant Germany that has resisted a continental initiative, until much later in the rapidly cascading financial crisis. The desperate attempt at resolving the financial crisis in Greece, and the pending one in Portugal, shows another example of reluctance of a continental, EU-sponsored rescue initiative. The US was not particularly creative and perspective in its approach either. For the world's largest economy, and widely believed country origins (genesis) of the crisis, the US displayed a level short-sightedness in leadership role in what, at best, was intellectual or ideological ambivalence and, at worst, a most inept fiscal and monetary policy initiative and articulation. The apparent tentativeness and irrationality that attended the indeterminate and unclear criteria for determining rescue recipients would lead to the redemption of Bear Stearns and Indy Bank early in the crisis, the inexplicable but extremely consequential and ill-advised refusal/failure to rescue LEHMAN BROTHERS, which was followed by, in the authors' opinion, a more pragmatic, if poorly structured and seemingly endless and expensive, rescue package for the likes of American International Group (AIG), General Motors (GM), etc.

Increasingly, there appears to be a fundamental disconnect between policy makers in the articulation and implementation of practical and pragmatic policy alternatives in the resolution of this global financial/market crisis and the free market orthodoxy that is unrealistically rooted in the ideological conflict of deregulation and regulation of markets. The false and unfounded notion and dichotomy of socialism, strictly so-called, and capitalism, strictly so-called, misrepresents the underlying dilemma. A resolution premised on either notion risks a misdiagnosis of the structural issues embedded in the crisis.

\section{CONCLUSION}

It would appear that unfettered deregulation, embodied in privatization, has produced an outcome disastrously inconsistent, if not traumatic, to sustainable global financial markets and operations. A more realistic and pragmatic re-formulation of the fundamentals of free market tenets, including regulation of capital and security instrument flows across the globe, has become imperative. A new process or initiative should articulate and implement a multilateral institutional support framework accommodating the full and equal participation of the developed, emerging and underdeveloped economies, along the Bretton Woods institution's model, but without its opaque operational, but ineffective, style. The danger appears to be that as the years go by and the memories of this global financial catastrophe recede in the sensibilities of nations and policy makers, it will be increasingly difficult to implement any comprehensive regulation by the major economies In the months ahead, we plan to focus our research in exploring and evaluating the contending paradigms with a view to finding workable and implementable alternatives. 


\section{AUTHOR INFORMATION}

Dr. Darlington Richards is a Professor in the Business Administration Department, Earl Graves School of Business and Management, Morgan State University, Baltimore Maryland USA.

Dr. Gladson I. Nwanna is a Professor in the Accounting \& Finance Department, Earl Graves School of Business and Management, Morgan State University, Baltimore Maryland USA.

\section{REFERENCES}

1. European Leaders to Meet Amid Economic Division (2009) New York Times International, February 28, A9.

2. New York Saturday, October 25, 2008.

3. The Economist, 2008.

4. $\quad$ New York Times, February 21, 2009.

5. New York Saturday, October 25, 2008.

6. New York Times, 2009 A9.

7. American Recovery and Reinvestment Act of 2009. 